\title{
THE ASSOCIATION BETWEEN LAND-USE DISTRIBUTION AND RESIDENTIAL PATTERNS: THE CASE OF MIXED ARAB-JEWISH CITIES IN ISRAEL
}

\author{
Ran GOLDBLATT, Itzhak OMER \\ Tel-Aviv University, Israel
}

\begin{abstract}
The emergence of GIS and the availability of high resolution geographic data have improved our ability to investigate the residential segregation in cities and to identify the temporal changes of the spatial phenomena. Using GIS, we have quantitatively and visually analyzed the correspondence between land-use distribution and Arab residential patterns and their changes in the period between 1983 and 2008 in five mixed ArabJewish Israeli cities. Results show a correspondence between the dynamics of Arab/ Jewish residential patterns and the spatial distribution of various land-uses. Arab residential patterns diffused faster towards areas with relatively inferior land-uses than towards areas with more attractive land-uses, in which a gentrification process occurred. Moreover, large-scale non-residential land-uses act as spatial partitions that divide between Arab and Jewish residential areas. Understanding the association between the urban environment and residential patterns can help in formulating an appropriate social and spatial policy concerning planning of land-uses and design of the built environment in mixed cities.
\end{abstract}

Key Words: ethnic residential segregation, land-uses, spatial continuity, residential dynamics, mixed cities

\section{Introduction}

The term mixed city is often used in the Israeli context to describe cities in which an Arab minority lives alongside a Jewish majority. Several studies have investigated the characteristics and development of the Israeli Arab-Jewish mixed cities, including planning and architectural aspects (Ben Artzi 1980,Yacobi 2002, Tamari 2004, Khamaisi 2008), segregation and residential patterns (Falah 1996, Omer 2005, Kipnis and Schnell 1978), as well as various social aspects like ethnicity and national narratives (Yiftachel and Yacobi 2003, Monterescu 2011) and interactions between Arabs and Jews in various life domains (Hadas and Gonen 1994, Falah et al. 2000).

However, the potential influence of the built environment on the formation of residential patterns, particularly in mixed cities, has not yet been fully explored. More specifically, while it is well known that the urban built environment and its various land-uses are related to the constitution of urban social areas and socio-spatial processes (Giddens 1984, Lefebvre 1991, Polednak 1993, Amin and Thrift 2002, Bolt et al. 2002) - including the formation of ethnic residential patterns (Rabin 1987, Boal 2002, Omer 2010) - to best of our knowledge, no extensive research has yet been conducted for exploring this relation in the context of Arab/ Jewish residential patterns in mixed Israeli cities. 
Moreover, the development of GIS (Geographic Information Systems) technology and the increasing availability of high resolution and good quality geographic data has encouraged research aimed to identify the spatial distribution of population groups, with a consideration given to their relative spatial location within the urban context (Omer 2010). The spatial analysis capabilities of GIS enable to use, in addition to population data, geometrical and topological information encoded in spatial data structure (Wong 2003, Wu and Sui 2001). Thus, GIS technology has the potential to enhance segregation studies by providing analytical mapping with high-resolution geo-referenced databases (e.g. census data). Previous GIS-based residential segregation studies have mainly concentrated on evaluating changes in segregation of residential patterns (Lesger and Van Leeuwen 2012, Lloyd et al. 2012, Gilliland et al. 2011) as well as in implementing spatial segregation measures at different geographic scales (as opposed to the traditional non-spatial structural measures such as the commonly used Dissimilarity index) (Wu and Sui 2001). However, little attention has been given to the correspondence between changes in social or ethnic residential patterns and the functional and physical attributes of the urban environment, such as the spatial structure and distribution of land-uses in the city.

Though several studies have investigated the characteristics and development of Israeli ArabJewish mixed cities, including the Arab-Jewish residential patterns (Yacobi 2002, Khamaisi 2008, Falah 1996), the correspondence between land-use distribution and Arab-Jewish residential patterns in the Israeli context, has not yet been fully explored.

In this paper we use GIS tools and analysis methods to investigate the correspondence between land-use distribution and the physical attributes of the built environment and the formation of Arab-Jewish residential patterns in five Israeli mixed cities. We explore the land-use characteristics of Arab and Jewish residential areas and we identify those land-uses that create spatial partitions between them. In the following section we discuss concepts of spatial segregation, as well as social and spatial factors that potentially facilitate residential distribution, followed by a description of the Israeli Arab-Jewish context. In the third section, we present the methodology followed by the research results. Conclusions and implications appear in the final paragraph.

\section{Land-use Distribution and Ethnic Residential Patterns}

Residential segregation refers to the residential location of various population groups in the urban space and reflects the relation between social differences and physical location in urban residential areas (Massey and Denton 1988). Residential segregation of minority groups results from internal group cohesiveness and own-group preferences as well as from majority-group attitudes of tolerance and institutional discrimination (Clark 2002, Johnston et al. 2007).

The relation between space and society goes back to the assumptions of Emile Durkheim, who treated space as socially in origin and spatial-physical divisions as corresponding with social divisions. Based on this perspective, the Chicago school (Burgess 1925) was among the first theories to deal with the relationship between spatial and social structures of cities. This school referred to the residential differentiation in ecological terms of segregation and assimilation, suggesting a correspondence between social assimilation of minority groups and a degree of spatial assimilation (Peach 2000, Hiebert and Ley 2003).

According to the "self-segregation" theory, social groups choose where to live partially by prejudices they hold about other groups, which lead them to favor living with others similar to them (Clark 1996) and to desire to strengthen their self-identity and political power (Boal 2002), 
or even to control residential and public space by creating "landscapes of exclusion" within a strongly classified environment (Sibley 1995). The "discrimination" theory claims that while the income and preferences of minority groups may allow them to move into "stronger" residential areas, other discriminatory housing market barriers sometimes prevent them from doing so (Peach 2000). Such market barriers may also be structurally inherent due to legislation by institutional authorities (Giddens 1984), which, by state laws and various regulations, can affect the accessibility of various population groups to housing resources (Smith 1987). The resulting segregation frequently has significant consequences on accessibility to essential public services, such as educational, social and medical services, and cultural amenities (Polednak 1993, Collins and Williams 1999).

However, residential segregation is often a matter of choice. Minority enclaves frequently represent destinations for incoming immigrants preferring specific residential locations, at least partially due to their contribution to internal group cohesiveness and opportunities (Johnston et al. 2007). At the same time, other factors also affect residential choices. These factors include socio-economic status and ethnic diversity within minority groups (Omer 2005, Bolt and Van Kempen 2010), dwelling prices (Owusu 1999), geographical distribution of housing types (Omer 2011), life cycle and the desire to improve living conditions (Hamadan 2006), as well as job opportunities and community infrastructure, such as the presence of communal educational and religious institutions (Boal 2002).

According to the "sentiment and symbolism" theory (Firey 1945), cultural properties of the built environment play an important role in residential choices of social groups. Communities tend to ascribe physical places in the city with collective sentimental associations (historic, cultural etc.), which may constitute a genuine, attractive force for certain cultural groups that, in turn, preserve these associations within their community (Scaff 1948). Sentimental associations sometimes generate an environment that maintains community conflict and group stereotyping (Boal 2002). On the other hand, "neutral" elements in the built environment sometimes moderate or even lessen residential segregation (Omer 2011). These characteristics play a role in the identification of places and neighborhoods in the city (Golledge and Stimson 1997) and in the identities that people establish (i.e. national identity), which allow them to differentiate themselves from others (Yacobi 2008).

The physical environment also affects dynamics of minority residential patterns through human experience, behavior, and individual preferences regarding residential choices. It allows, facilitates, or prevents various mental and behavioral acts, mainly through three distinct physical and spatial characteristics of the urban built environment (Weisman 1981, Montello 2007): differentiation (i.e. the degree to which different parts of the built environment have a unique layout, such as size, color, and shape); complexity (i.e. the composition and organization of spaces and street networks), and visibility (i.e. the degree to which different places and features in an environment are visually connected).

Since the Chicago School, many studies have investigated the association between the spatial distribution of social groups and the characteristics of the physical urban environment, including the distribution of land-uses (Boal 2002, Galster and Cutsinger 2007, Omer 2011) and the spatial configuration of the urban street network (Grannis 1998, 2005; Vaughan 2007, Omer and Goldblatt 2012). Generally, these studies suggest that less accessible and isolated neighborhoods surrounded by physical obstacles tend to differ from their surrounding area in their socio-economic and ethnic characteristics. While pedestrian streets connecting neighborhoods were found to be a moderating feature of segregation (Grannis 2005, Omer and Goldblatt 2012), other spatial features sometimes function as obstacles that prevent social 
groups from expanding and from being within walking distance with one another. For example, according to an economic survey conducted in London in the $19^{\text {th }}$ century, poverty areas in the city tended to be "literally walled-off from the rest of the city by barrier-like boundaries that isolated their inhabitants, minimizing their normal participation in the life of the city about them..." (Pfautz 1967: 120). In another research conducted in 50 American cities, Rabin (1987) found that black and white residential neighborhoods were often divided by the discontinuous system of residential streets with access between the neighborhoods primarily through nonresidential streets. Similar conditions have been reported by Dupont (2004) who found that the Yamuna River, with its large bed of agricultural land, and the natural forest of the Aravalli Hills act as demarcation lines between urban sectors in Delhi, India.

\section{The Israeli Context: Arab-Jewish Mixed Cities}

In 2010, Palestinian Arab citizens constituted approximately $16.5 \%$ of the state's population (Smoocha 2010) with roughly 1.25 million residents. While the majority of Israeli Arabs are Muslims (82\%), they also include Christians and Druze ( $9 \%$ and $9 \%$, respectively). The vast majority of Jews and Arabs live in well-defined, homogenous and separated Jewish or Arab villages, townships and cities, while approximately $10 \%$ of Israeli Arab citizens reside, as a minority, in seven mixed cities (not including Jerusalem): five old cities (established before 1948) - Haifa, Jaffa, Acre, Lod, Ramle; and two new cities - Natzrat Illit and Ma'alot-Tarshiha ${ }^{1)}$ (Fig. 1). Though these cities differ in their ethnic composition and demographic characteristics (Table 1), their residential patterns evolved relatively similarly.

Characteristics of the mixed Israeli Cities, 2008

\begin{tabular}{|c|c|c|c|c|c|c|c|}
\hline City & Pop* & Jews (\%) & \multicolumn{4}{|c|}{ Arabs (\%) } & \\
\hline & & & Total & Muslim & Christian & Druze & Area (sq km) \\
\hline Acre & 46,3 & 66.4 & 28.3 & 90.9 & 8.5 & 0.6 & 13.5 \\
\hline Haifa & 264,8 & 80.9 & 10.2 & 46.1 & 51.9 & 0.98 & 68.9 \\
\hline $\mathrm{Jaffa}^{\mathrm{a}}$ & 45,9 & 63.8 & 33.3 & 79.4 & 20.4 & 0.0 & 4.83 \\
\hline Lod & 67,5 & 67.5 & 24.9 & 95.3 & 4.6 & 0.0 & 12.2 \\
\hline Ramle & 65.5 & 73.4 & 23.0 & 80.0 & 19.7 & 0.2 & 11.9 \\
\hline
\end{tabular}

${ }^{a}=$ Estimated number on the basis of the 2008 Population and Housing Census and the 2009 Tel-Aviv-Jaffa Municipality Annual Survey; ${ }^{*}=$ numbers in thousands; Source: The Israeli Local Authorities 2008, publication No. 1414, The 2008 Population Housing Census, Israeli Central Bureau of Statistics.

Two main residential patterns characterize these cities: mixed (where Jews and Arabs reside in the same neighborhoods), and separated (homogenous Arab and Jewish neighborhoods), as shown in Figure 2. In general, the Arab population of these cities resides in homogenous Arab neighborhoods, while a small minority resides in adjacent mixed areas.

1) In this research we concentrate only on the old "typical" mixed cities. The development and characteristics of the "new" mixed cities are different than the "old" cities. Namely, the majority of the Arab population in Maalot-Tarshiha and Natzratlllit are not natives at the cities. Arabs did not reside in Natzratlllit when it was established in 1957 as a Jewish city and Maalot-Tarshiha was established by the union of two cities: the Jewish Maalot and the Arab Tarshiha, to one unified municipality, which was declared as a city in 1996. Generally, the majority of the Arab population in this city resides in the former Tarshiha while the Jewish population resides in the former Maalot. 


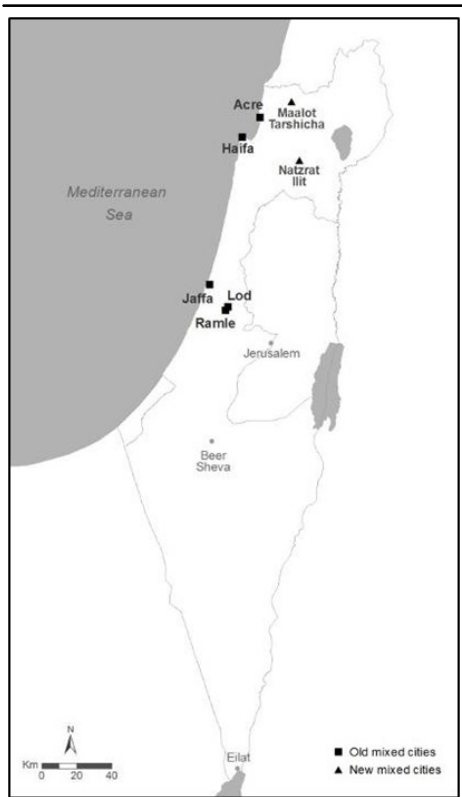

Fig. 1 - The mixed Israeli cities

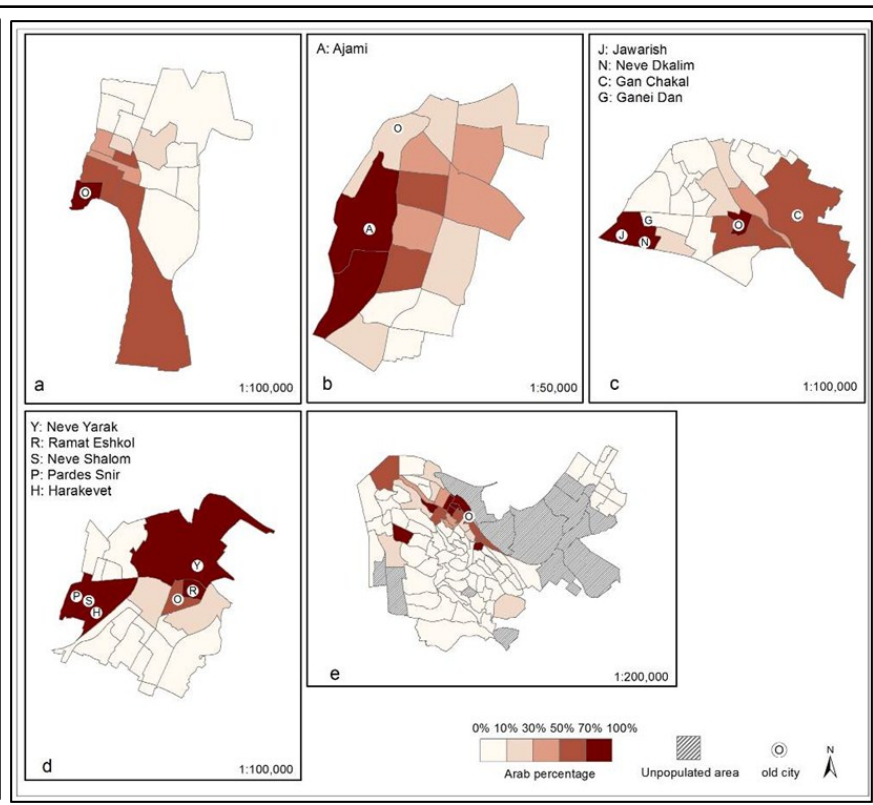

Fig. 2 - The Arab population distribution in the mixed cities in 2008: a. Acre, b. Jaffa, c. Ramle, d. Lod, e. Haifa

However, these residential patterns are not static and they are constantly evolving. Arabs initially settled in homogenous Arab neighborhoods and gradually expanded into neighboring Jewish areas due to the lack of residential solutions, progressively changing them into mixed or Arab neighborhoods (Khamaisi 2008).

\section{Materials and Methods}

The analysis of the association between the built environment's attributes and the residential patterns was conducted in several stages. First, the analysis of the correspondence between land-use distribution with (1) Arab residential patterns in $2008^{2)}$, and (2) ethnic composition change in the period between 1983 and 2008. Second, the analysis of land-uses that function as spatial partitions in the interface zones dividing Arab and Jewish residential areas.

Analysis of Arab residential distribution was based on the ICBS's 1983 and 2008 Population and Housing Census, using the statistical area geographical unit scale, within a GIS framework $^{3), 4}$. Intensity of ethnic composition changes and the subsequent dynamics of Arab

2) Detailed demographic data at the statistical area geographical unit scale is published by the ICBS as part of the Population and Housing Census approximately every 12 years. The latest census was published in 2008

3) The data, obtained from the 1983 and 2008 ICBS (Israel Central Bureau of Statistics) Population and Housing Census, includes information about each statistical area's demographic and ethnic characteristics. Changes in size and pattern of Arab residential distribution were analyzed for the period between 1983 and 2008 by comparing the data on Arab residential distribution, per statistical area, between both years. Major changes in the statistical area's distribution and boundaries did not allow a reliable comparison with surveys prior to 1983.

4) The statistical unit is the smallest unit that the ICBS makes available to the public. Census tracts are defined by ICBS as "small and homogenous units that enable analysis of statistical data in small geographical units. Each unit is comprised of between $3000-4000$ persons". 
and Jewish residential patterns were revealed by computing the annual rate of change of the Arab population for each statistical area, as follows: $\left(P t 2_{x}-P t 1_{x}\right) / T$, where $P$ is the percentage of the Arab population in statistical area $x$ in 2008 [t2] and in 1983 [t1]; T denotes the difference between years of the censuses ${ }^{5}$. Such analysis enabled us not only to visually compare between the Arab spatial distributions in the two time frames, but also to quantitatively define various change-paces and to compare between the cities.

Land-use distribution data was obtained as GIS layers from the Survey of Israel (MAPI) and the "Mapa" company'). The data, obtained as a point layer ${ }^{7)}$, includes the spatial location and usage of all residential and non-residential land-uses. The land-uses were classified into eight categories: (i) commerce, (ii) education and research, (iii) public services (including health and welfare), (iv) industry and agriculture, (v) Jewish worship institutes, (vi) mixed residential buildings (combining residence with another land-use), (vii) Muslim and Christian worship institutes, and (viii) sports and culture land-uses. Examples of land-uses included in each landuse category appear in appendix 1.

In order to take into account the varying sizes of the examined statistical areas, we computed for each statistical area the number of buildings belonging to each of the eight categories as a percentage of the total number of buildings in the area (including residential buildings).

Appendix 1

\section{Examples of land-uses included in each land-use category}

\begin{tabular}{|l|l|}
\hline Commerce & Commercial center, mall, market, store, bank, event hall. \\
\hline Education, research & $\begin{array}{l}\text { University, school (e.g. high school, junior high school, } \\
\text { elementary school), academic institute, kindergarten, Talmudic } \\
\text { college, religious school. }\end{array}$ \\
\hline Health, public services & $\begin{array}{l}\text { Retirement home, geriatric center, hospital, detention center, } \\
\text { court (e.g. magistrates court, district court), pharmacy, } \\
\text { cemetery, municipality, medical institute, first aid station, police } \\
\text { station. }\end{array}$ \\
\hline $\begin{array}{l}\text { Industry, Agriculture } \\
\text { Jewish worship }\end{array}$ & $\begin{array}{l}\text { Industrial area, production plant, packing house, nursery, dairy } \\
\text { farming, pen. }\end{array}$ \\
\hline $\begin{array}{l}\text { Muslim \& Christian } \\
\text { Worship }\end{array}$ & $\begin{array}{l}\text { Synagogue, Jewish religious institute (excluding synagogue and } \\
\text { Cemetery). }\end{array}$ \\
\hline Sports, Culture & $\begin{array}{l}\text { Sport center, opera, archeological site, historic site, public } \\
\text { swimming pool, stadium, memorial site. }\end{array}$ \\
\hline \hline
\end{tabular}

5) Due to differences in the divisions of some statistical areas for the two time periods (areas had been merged, split or added), some adjustments were made in order to facilitate the comparison between the two time periods. We computed the Arab proportion for statistical areas that had merged by 2008 by combining the 1983 census data for these areas. Areas that split in 2008 were excluded from the comparison.

6) The Survey of Israel is the official Israeli government agency for Mapping, Geodesy, Cadastre and Geoinformatics. "Mapa - Mapping and Publishing Ltd." is a private company. All data is updated to 2011.

7) The data does not include the area of the built structure. However, for the purpose of this research, the data is sufficient enough and reflects the use and meaning associated with the land-uses. 
The analysis of the relation between the 2008 Arab residential distribution and the land-use distribution was done using a Two-tailed Pearson correlation test, in which we compared the Arab population percentage with the percentage of the various land-use categories in each statistical area. In addition, to better understand the correspondence between land-use distribution and residential patterns, the statistical areas in each city were classified into 3 residential patterns: Jewish, mixed and Arab (as will be described below). Each area was then analyzed to identify its land-use characteristics.

Analysis of the relation between the annual change in Arab residential patterns and land-use distribution between 1983 and 2008 was done by classifying each city's statistical areas according to three trends in the Arab population change rate during that period: (a) a decrease, (b) a slow increase, and (c) a rapid increase, as will be described below. We then computed the number of buildings belonging to the eight land-use categories as a percentage of the total number of buildings for each area.

The analysis of the characteristics of the land-uses located in the interface zones between Arab and Jewish residential areas was done by identifying the adjacent statistical areas that exhibit the greatest differences in the percentage of Arab population. This was done by converting the polygonal layer of the statistical areas into a polyline layer, with the lines 'values representing the difference between each pair of adjacent statistical areas. We then analyzed the land-use characteristics of these dividing zones. This allowed us to identify the type and characteristics of the spatial partitions dividing between Arab and Jewish residential areas. The data was analyzed using SPSS v. 16.00 and it was analyzed and presented in ArcGIS v.10.00.

\section{Results}

\section{Land-Use Distribution and Arab Residential Patterns}

Examination of the correspondence between the Arab residential patterns in 2008 (reflected by the percentage of Arabs in each statistical area) and the land-use distribution in all cites (Table 2) shows a significant positive correlation in several land-use categories: Muslim and Christian worship institutes $(r=0.54, p<0.00)$, mixed residential buildings $(r=0.35, p<0.00)$, commercial land-use $(r=0.33, p<0.00)$, and industry and agriculture land-use $(r=0.23, p<0.05)$. A high ratio of Arab population is also associated with areas with a relatively high percentage of commercial land-use and Muslim and Christian worship institutes, when investigating each city separately. In the case of Jaffa, only sports and culture land-uses were found to be (negatively) correlated $(r=-0.56, p<0.05)$ with the Arab population distribution. In Acre, for example, this correlation is significantly positive $(r=0.64, p<0.01)$, mainly due to the relatively high number of culture land-use buildings located in the older Arab areas, as compared to the city's northern Jewish neighborhoods. The differences in correlations between the cities result from the unique distribution of the physical and social attributes in each city and from the unique history and temporal changes of each city's Arab population. For example, in Acre, Lod and Ramle commercial land-uses are located in or around the core area of the Arab population, and hence, these cities are characterized by a positive significant correlation between the presence of Arab population and commercial land-uses. Against that, in Jaffa, commercial land-uses are located relatively far from the Arab historic core area, which leads to a negative correlation between these two variables. Interestingly, none of the investigated cities demonstrated a significant correlation between Arab-Jewish distribution and the presence of Jewish worship institutes. The same tendency was found concerning the presence of public services and education and research institutes, i.e. the correspondence with the Arab-Jewish residential distribution is weak. 
Correlation between land-use category percentages and the ratio of the Arab population at the statistical area level

\begin{tabular}{|c|c|c|c|c|c|c|c|c|}
\hline & Commerce & $\begin{array}{l}\text { Education, } \\
\text { Research }\end{array}$ & $\begin{array}{l}\text { Health, } \\
\text { Public } \\
\text { Services }\end{array}$ & $\begin{array}{l}\text { Industry, } \\
\text { Agriculture }\end{array}$ & $\begin{array}{c}\text { Jewish } \\
\text { worship } \\
\text { institutes }\end{array}$ & $\begin{array}{c}\text { Mixed } \\
\text { Residential } \\
\text { Building }\end{array}$ & $\begin{array}{l}\text { Muslim \& } \\
\text { Christian } \\
\text { Worship }\end{array}$ & $\begin{array}{l}\text { Sports, } \\
\text { Culture }\end{array}$ \\
\hline \multirow{2}{*}{$\begin{array}{l}\text { Acre } \\
\left(n^{a}=16\right)\end{array}$} & $r^{* * *}=0.77$ & $r=-0.18$ & $r=0.23$ & $r=0.34$ & $r=-0.13$ & $r^{* * *}=0.68$ & $r^{* * *}=0.67$ & $r^{* * *}=0.64$ \\
\hline & $p=0.00$ & $p=0.51$ & $p=0.40$ & $r=0.20$ & $p=0.62$ & $p=0.00$ & $p=0.01$ & $p=0.01$ \\
\hline \multirow{2}{*}{$\begin{array}{l}\text { Haifa } \\
\left(n^{a}=90\right)\end{array}$} & $r^{*}=0.19$ & $r=0.02$ & $r=0.04$ & $r^{* *}=0.24$ & $r^{*}=-0.18$ & $r^{* * *}=0.49$ & $r^{* * *}=0.61$ & $r=0.02$ \\
\hline & $p=0.08$ & $p=0.86$ & $p=0.70$ & $p=0.02$ & $p=0.09$ & $p=0.00$ & $p=0.00$ & $p=0.88$ \\
\hline \multirow{2}{*}{$\begin{array}{l}\text { Jaffa } \\
\left(n^{a}=16\right)\end{array}$} & $r=-0.27$ & $r=-0.27$ & $r=-0.10$ & $r=-0.52$ & $r=-0.26$ & $r=-0.15$ & $r=0.01$ & $r^{* *}=-0.56$ \\
\hline & $p=0.32$ & $p=0.31$ & $p=0.71$ & $p=0.85$ & $p=0.34$ & $p=0.58$ & $p=0.97$ & $p=0.02$ \\
\hline \multirow{2}{*}{$\begin{array}{l}\text { Lod } \\
\left(n^{a}=19\right)\end{array}$} & $r^{* *}=0.51$ & $r=-0.23$ & $r=-0.03$ & $r^{* *}=0.47$ & $r=-0.26$ & $r=0.23$ & $r^{* * *}=0.79$ & $r=-0.23$ \\
\hline & $p=0.03$ & $p=0.35$ & $p=0.91$ & $p=0.04$ & $p=0.28$ & $p=0.33$ & $p=0.00$ & $p=0.35$ \\
\hline \multirow{2}{*}{$\begin{array}{l}\text { Ramle } \\
\left(n^{a}=21\right)\end{array}$} & $r^{* * *}=0.58$ & $r^{*}=-0.39$ & $r=0.26$ & $r=0.31$ & $r=-0.33$ & n.a. & $r^{* * *}=0.80$ & $r=-0.33$ \\
\hline & $p=0.01$ & $p=0.08$ & $p=0.27$ & $p=0.17$ & $p=0.14$ & n.a. & $p=0.00$ & $p=0.14$ \\
\hline \multirow{2}{*}{$\begin{array}{l}\text { All cities } \\
\left(n^{a}=162\right)\end{array}$} & $r^{* * *}=0.33$ & $r=-0.04$ & $r=0.10$ & $r^{* *}=0.23$ & $r=-0.12$ & $r^{* * *}=0.35$ & $r^{* * *}=0.54$ & $r=0.00$ \\
\hline & $p=0.00$ & $p=0.64$ & $p=0.21$ & $p=0.04$ & $p=0.13$ & $p=0.00$ & $p=0.00$ & $p=0.98$ \\
\hline
\end{tabular}

${ }^{a} n=$ number of statistical areas; ${ }^{*} p<.1,{ }^{* *} p<.05,{ }^{* * *} p<.01$

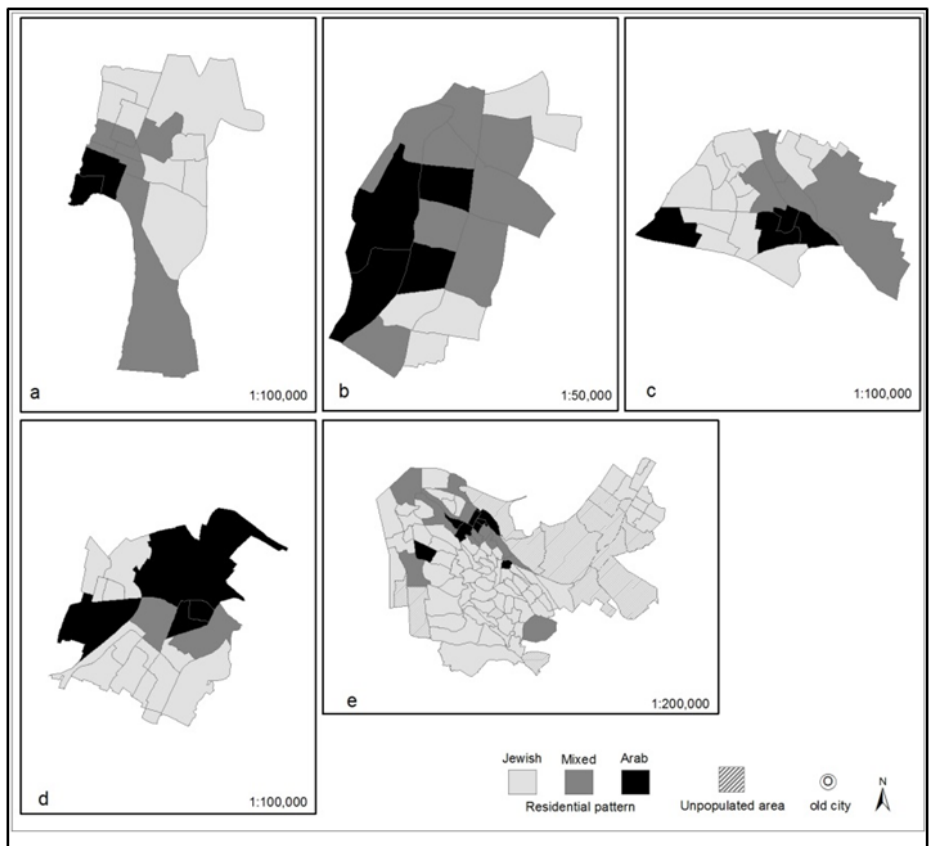

Fig. 3 - Distribution of Jewish (Arab percent < 15\%), Arab (Arab percent $>60.1 \%$ ) and Mixed (Arab percent between $15.1 \%$ and $60 \%$ ) areas (per statistical area, 2008), in a. Acre, b. Jaffa, c. Ramle, d. Lod, e. Haifa 
These results can be understood when examining the spatial distribution of the cities 'various public land-uses in three categories of Arab-Jewish population composition: Arab (higher than $60.1 \%$ Arabs), Jewish (less than 15\% Arabs), and mixed (between $15.1 \%$ and $60 \%$ Arabs). Figure 3 presents the spatial distribution of these areas and Table 3 presents the percentage of buildings per land-use category in each residential pattern.

Table 3

Percentage of buildings per land-use category in A: Arab (Higher than $30.1 \%$ Arabs), M: Mixed (15.1\%-60\% Arabs) and J: Jewish (less than 15\% Arabs)

\begin{tabular}{|c|c|c|c|c|c|c|c|c|c|}
\hline & & Commerce & $\begin{array}{l}\text { Education, } \\
\text { Research }\end{array}$ & $\begin{array}{l}\text { Health, } \\
\text { Public } \\
\text { Services }\end{array}$ & $\begin{array}{l}\text { Industry, } \\
\text { Agriculture }\end{array}$ & $\begin{array}{l}\text { Jewish } \\
\text { worship } \\
\text { institutes }\end{array}$ & $\begin{array}{c}\text { Mixed } \\
\text { Residential } \\
\text { Building }\end{array}$ & $\begin{array}{l}\text { Muslim \& } \\
\text { Christian } \\
\text { Worship }\end{array}$ & $\begin{array}{l}\text { Sports, } \\
\text { Culture }\end{array}$ \\
\hline \multirow{3}{*}{$\begin{array}{c}\text { Acre } \\
\left(n^{a}=3,501\right)\end{array}$} & A & $19.85 \%$ & $254 \%$ & $6.05 \%$ & $0.36 \%$ & $0.73 \%$ & $9.08 \%$ & $1.21 \%$ & $2.30 \%$ \\
\hline & $\mathrm{J}$ & $4.78 \%$ & $3.52 \%$ & $4.57 \%$ & $0.00 \%$ & $1.21 \%$ & $0.95 \%$ & $0.11 \%$ & $0.95 \%$ \\
\hline & $\bar{M}$ & 20.77 & $4.66 \%$ & $6.60 \%$ & $7.50 \%$ & $1.94 \%$ & $1.68 \%$ & $0.00 \%$ & $3.62 \%$ \\
\hline \multirow{3}{*}{$\begin{array}{c}\text { Haifa } \\
\left(n^{a}=26,892\right)\end{array}$} & A & $9.39 \%$ & $0.96 \%$ & $2.02 \%$ & $0.39 \%$ & $0.09 \%$ & $6.27 \%$ & $0.66 \%$ & $0.44 \%$ \\
\hline & $\mathrm{J}$ & $3.87 \%$ & $1.11 \%$ & $1.28 \%$ & $0.06 \%$ & $0.48 \%$ & $1.94 \%$ & $0.01 \%$ & $0.67 \%$ \\
\hline & $\mathrm{M}$ & $11.41 \%$ & $238 \%$ & $3.17 \%$ & $0.68 \%$ & $0.41 \%$ & $8.52 \%$ & $0.03 \%$ & $1.20 \%$ \\
\hline \multirow{3}{*}{$\begin{array}{c}\text { Jaffa } \\
\left(n^{a}=4,710\right)\end{array}$} & A & $0.86 \%$ & $1.04 \%$ & $1.11 \%$ & $0.00 \%$ & $0.12 \%$ & $0.58 \%$ & $0.52 \%$ & $0.52 \%$ \\
\hline & $\mathrm{J}$ & $0.90 \%$ & $1.41 \%$ & $1.92 \%$ & $0.00 \%$ & $0.30 \%$ & $0.40 \%$ & $0.00 \%$ & $2.21 \%$ \\
\hline & $\mathrm{M}$ & $1.77 \%$ & $1.21 \%$ & $1.38 \%$ & $0.20 \%$ & $0.40 \%$ & $1.11 \%$ & $0.30 \%$ & $1.16 \%$ \\
\hline \multirow{3}{*}{$\begin{array}{c}\text { Lod } \\
\left(n^{a}=3,777\right)\end{array}$} & A & $11.93 \%$ & $3.43 \%$ & $3.20 \%$ & $2.98 \%$ & $2.25 \%$ & $2.87 \%$ & $0.88 \%$ & $0.88 \%$ \\
\hline & $\mathrm{J}$ & $3.50 \%$ & $5.08 \%$ & $249 \%$ & $0.10 \%$ & $0.99 \%$ & $0.91 \%$ & $0.00 \%$ & $1.63 \%$ \\
\hline & $M$ & $5.72 \%$ & $3.43 \%$ & $5.08 \%$ & $0.76 \%$ & $1.14 \%$ & $1.78 \%$ & $0.13 \%$ & $0.64 \%$ \\
\hline \multirow{3}{*}{$\begin{array}{c}\text { Ramle } \\
\left(n^{\mathrm{a}}=4,186\right)\end{array}$} & A & $12.0 \%$ & $4.2 \%$ & $3.0 \%$ & $1.0 \%$ & $1.7 \%$ & n.a. & $0.9 \%$ & $0.9 \%$ \\
\hline & $\mathrm{J}$ & $3.9 \%$ & $2.1 \%$ & $2.1 \%$ & $0.0 \%$ & $1.8 \%$ & n.a. & $0.0 \%$ & $1.6 \%$ \\
\hline & $M$ & $9.9 \%$ & $2.4 \%$ & $6.3 \%$ & $2.1 \%$ & $1.0 \%$ & n.a. & $0.3 \%$ & $0.8 \%$ \\
\hline
\end{tabular}

${ }^{a} \mathrm{n}=$ number of residential and non-residential buildings

\section{Changes in the Ethnic Residential Patterns between 1983 and 2008 and Public Land-Use Distribution}

According to the ICBS, between 1983 and 2008, the five investigated cities experienced a moderate but consistent increase of the Arab population rate, while a decrease of the Jewish one (Table 4). A detailed examination of changes in Arab population distribution for this period (expressed by the annual change rate in each statistical area) (Fig. 4) reveals that the Arab residential pattern in all cities has generally been characterized by a diffusion form. Because the changes are presented for the period between 1983 and 2008, the Arab population rate did not significantly change in the cities' historic areas but mostly in the cities peripheral parts. This diffusion form of the Arab's residential patterns can be explained primarily by two processes: invasion-succession (Berry and Kasarda 1977) and spatial diffusion (Morrill 1970), in which minority populations expand into contiguous neighborhoods occupied by the majority group, resulting in a spatial diffusion process. 


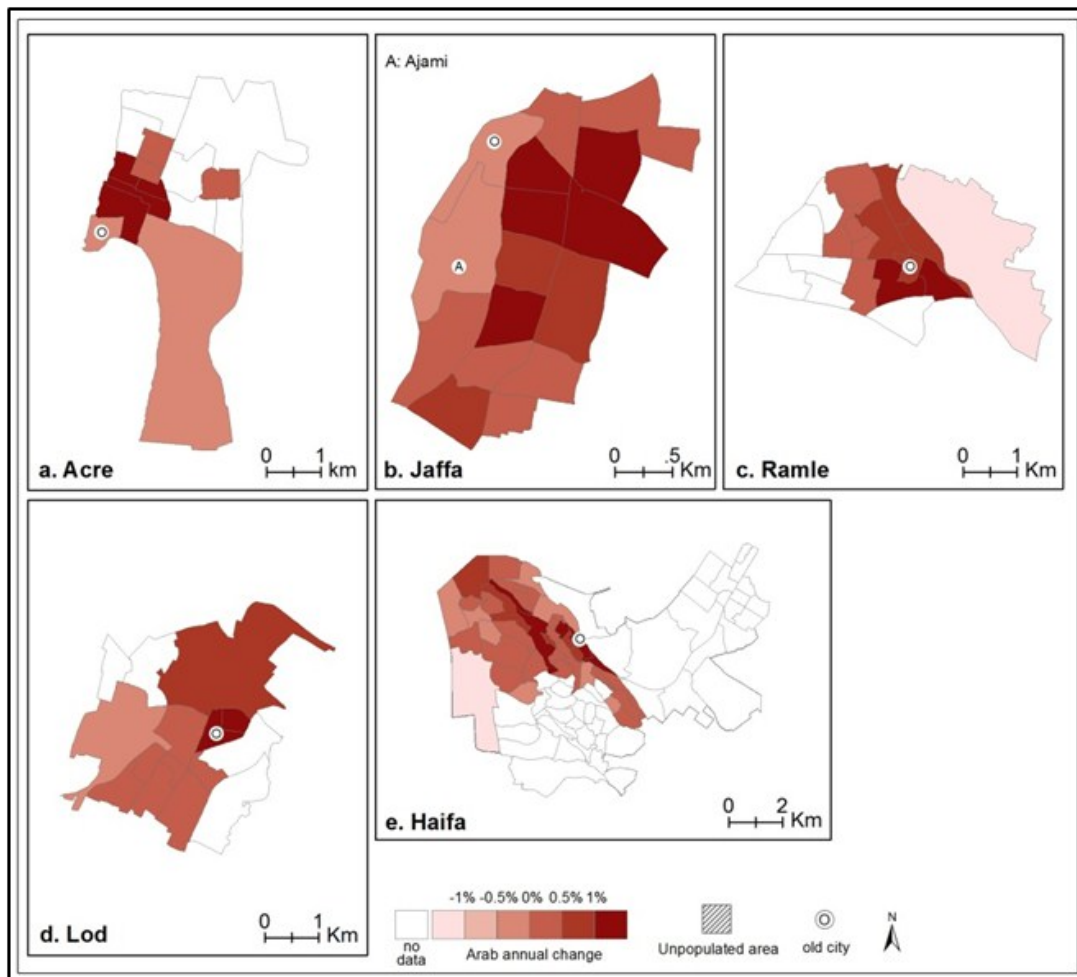

Fig. 4 - Annual change rate of the Arab population between 1983 and 2008, in: a. Acre, b. Jaffa, c. Ramle, d. Lod, e. Haifa

Table 4

Changes in the cities' Arab and Jewish Populations between 1983 and 2008

\begin{tabular}{|l|c|c|c|c|c|c|c|}
\hline & \multicolumn{3}{|c|}{1983} & \multicolumn{3}{c|}{2008} & $\begin{array}{c}\text { Change between } \\
1983-2008\end{array}$ \\
\hline & Arabs* $^{*}$ & Jews* & Arab\% & Arabs* & Jews* & Arab\% & Arab\% \\
\hline Acre & 7.7 & 27.6 & $21.2 \%$ & 13.1 & 30.7 & $28.3 \%$ & $+7.1 \%$ \\
\hline Haifa & 17.4 & 208.2 & $7.7 \%$ & 27.0 & 214.2 & $10.2 \%$ & $+2.5 \%$ \\
\hline Jaffa & 8.0 & 28.9 & $21.8 \%$ & 12.9 & 21.5 & $34.3 \%$ & $+12.5 \%$ \\
\hline Lod & 6.7 & 33.8 & $16.5 \%$ & 16.8 & 45.6 & $24.9 \%$ & $+8.4 \%$ \\
\hline Ramle & 6.2 & 36.0 & $14.8 \%$ & 15.1 & 48.1 & $23.0 \%$ & $+8.2 \%$ \\
\hline
\end{tabular}

*numbers in thousands

As demonstrated in Figure 4, the level of change in Arab residential distribution is not uniform throughout the cities. The question that now arises is what are the land-use characteristics of the different residential areas and how do they correspond with Arab residential change. 
Table 5 presents the percentage of buildings belonging to each land-use category in areas characterized by a decrease of Arab population (i.e., a negative annual change rate), a slow increase (annual change rate between $0.1 \%$ and $1 \%$ per year), and a rapid increase (annual change rate higher than $1 \%$ per year). When looking at all cities (see bottom of Table 5), results show that areas in which the Arab population decreased (and the Jewish population increased) are characterized by the highest percentage of commercial land-uses, as well as by the highest percentage of sports and culture and public services $(9.66 \%, 1.17 \%$, and $3.20 \%$ of all buildings, respectively). At the same time, areas that experienced a rapid increase of the Arab population are characterized by the lowest percentage of positive and attractive land-uses, such as education and research and sports and culture land-uses $(1.72 \%$ and $0.79 \%$, respectively).

Table 5

Percent of buildings per land-use category for each annual change rate pace ${ }^{a}$

\begin{tabular}{|c|c|c|c|c|c|c|c|c|c|c|}
\hline & $\begin{array}{l}\text { Change } \\
\text { rate }\end{array}$ & $N^{b}$ & $\begin{array}{l}\text { Com- } \\
\text { merce }\end{array}$ & $\begin{array}{l}\text { Education, } \\
\text { Research }\end{array}$ & $\begin{array}{l}\text { Industry, } \\
\text { Agriculture }\end{array}$ & $\begin{array}{l}\text { Muslim } \\
\quad \& \\
\text { Christian } \\
\text { Worship }\end{array}$ & $\begin{array}{c}\text { Jewish } \\
\text { Worship }\end{array}$ & \begin{tabular}{|c|} 
Mixed \\
Residential \\
Building
\end{tabular} & $\begin{array}{l}\text { Sports, } \\
\text { Culture }\end{array}$ & $\begin{array}{l}\text { Public } \\
\text { Ser- } \\
\text { vices }\end{array}$ \\
\hline \multirow[t]{3}{*}{ Acre } & $<0 \%$ & 522 & 32.95 & 2.11 & 11.30 & 1.72 & 0.19 & 4.21 & 5.17 & 6.13 \\
\hline & $0 \%-1 \%$ & 537 & 7.08 & 6.33 & 0.00 & 0.19 & 2.79 & 0.19 & 1.86 & 6.52 \\
\hline & $>1 \%$ & 958 & 15.76 & 2.82 & 0.21 & 0.10 & 1.15 & 6.58 & 1.57 & 6.58 \\
\hline \multirow[t]{3}{*}{ Jaffa } & $<0 \%$ & 941 & 1.49 & 0.96 & 0.11 & 1.17 & 0.11 & 0.74 & 1.06 & 1.17 \\
\hline & $0 \%-1 \%$ & 2393 & 1.50 & 1.30 & 0.00 & 0.04 & 0.33 & 0.79 & 1.59 & 1.38 \\
\hline & $>1 \%$ & 1376 & 0.65 & 1.16 & 0.22 & 0.22 & 0.29 & 0.73 & 0.44 & 2.11 \\
\hline \multirow[t]{3}{*}{ Lod } & $<0 \%$ & 338 & 7.10 & 5.92 & 0.59 & 0.59 & 1.18 & 2.37 & 0.89 & 4.44 \\
\hline & $0 \%-1 \%<$ & 2452 & 5.34 & 4.32 & 1.26 & 0.04 & 1.96 & 1.18 & 1.35 & 3.10 \\
\hline & $>1 \%$ & 369 & 15.45 & 4.34 & 0.54 & 1.36 & 2.44 & 5.15 & 1.36 & 3.25 \\
\hline \multirow[t]{3}{*}{ Ramle } & $<0 \%$ & 395 & 13.67 & 3.54 & 5.06 & 0.25 & 1.01 & n.a. & 1.52 & 5.82 \\
\hline & $0 \%-1 \%$ & 2273 & 6.82 & 3.43 & 0.22 & 0.31 & 1.76 & n.a. & 1.10 & 3.12 \\
\hline & $>1 \%$ & 657 & 8.83 & 1.67 & 0.91 & 0.15 & 1.98 & n.a. & 0.76 & 3.50 \\
\hline \multirow[t]{3}{*}{ Haifa } & $<0 \%$ & 3437 & 8.15 & 1.54 & 0.20 & 0.32 & 0.35 & 4.16 & 0.58 & 2.88 \\
\hline & $0 \%-1 \%$ & 9330 & 6.61 & 1.01 & 0.04 & 0.06 & 0.51 & 5.40 & 0.75 & 1.88 \\
\hline & $>1 \%$ & 1937 & 5.73 & 1.08 & 1.19 & 0.00 & 0.26 & 4.54 & 0.57 & 1.14 \\
\hline \multirow{3}{*}{$\begin{array}{l}\text { All } \\
\text { cities }\end{array}$} & $<0 \%$ & 5633 & 9.66 & 1.90 & 1.58 & 0.60 & 0.39 & 3.20 & 1.17 & 3.20 \\
\hline & $0 \%-1 \%$ & 16985 & 5.75 & 2.03 & 0.24 & 0.09 & 0.94 & 3.26 & 1.04 & 2.30 \\
\hline & $>1 \%$ & 5297 & 7.29 & 1.72 & 0.68 & 0.19 & 0.79 & 3.40 & 0.79 & 2.81 \\
\hline
\end{tabular}

${ }^{a}$ change rate $=$ the annual change rate of the Arab population at each statistical area.

${ }^{\mathrm{b}} \mathrm{N}=$ number of residential and non-residential buildings

A detailed examination of the cities' land-use distribution (see Fig. 5 with selected cases) shows that in three cities (Acre, Ramle and Haifa) areas that experienced a decrease of the Arab population are characterized by the highest percentage of commercial land-uses. Only in 
Lod the highest percentage of commercial land-uses is found in areas in which the Arab population had rapidly increased (see Fig. 5b). Lod is also an exception in regard to sports and culture land-uses; in all cities but Lod, areas that showed a rapid increase of the Arab population are characterized by the lowest percentage of these land-uses. Moreover, in three of the cities (Lod, Ramle and Haifa), the highest percentage of education and research land-uses is found in areas in which the Arab population had decreased (namely, areas into which Jews moved into).

Unexpectedly, the highest percentage of Muslim and Christian worship institutes was found in areas that showed a decrease of Arab population. This is demonstrated in the case of Acre, Jaffa and Haifa, where the highest percentage of Muslim and Christian worship institutes is found in areas into which Jewish population has entered (see, for example, Fig. 5a and Fig. 5c with selected areas in Haifa and Jaffa). This implies that religious institutes do not play a significant role in residential decisions among the population. Thus, the results supports the notion that the gentrification process, whereby the Jewish majority penetrates the Arab minority's residential areas and pushes out the minority residents, is associated with relatively more positive and attractive land-uses (e.g. sports and culture and education and research land -uses) while areas into which the Arab population has entered are characterized by a much lower percentage of these positive land-uses.

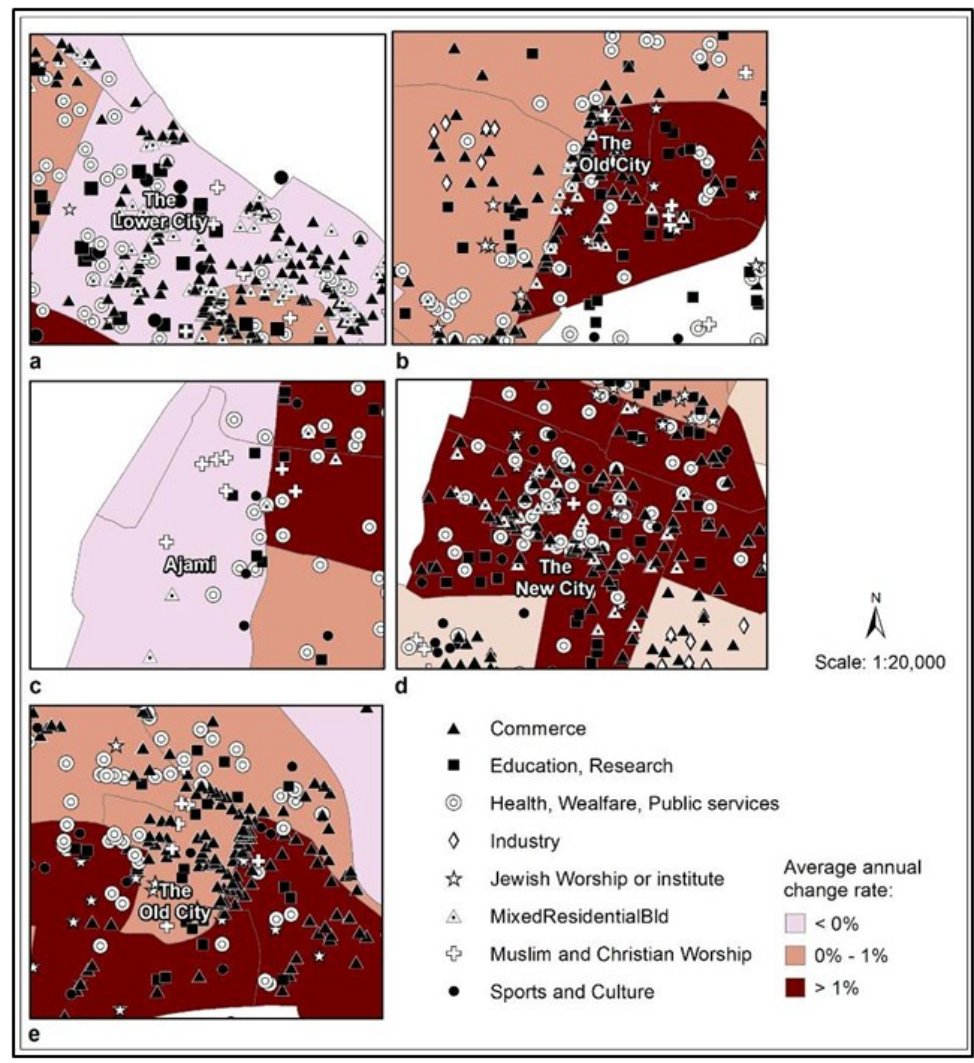

Fig. 5 - Distribution of the Arab population and of public land-uses (selected areas), in a. Haifa, b. Lod, c. Jaffa, d. Acre, e. Ramle 
The Association between Land-Use Distribution and Residential Patterns: the Case of Mixed Arab-Jewish Cities in Israel

\section{Spatial Partitions as Social Boundaries}

While various land-uses may affect the evolvement of ethnic residential patterns in mixed areas due to their functional and symbolic meaning, certain land-uses also serve as spatial partitions due to their physical and spatial characteristics that provide conditions facilitating separation, or segregation, between ethnic and social groups (Rabin 1987, Grannis 2005, Omer and Goldblatt 2012). Large-scale land-uses often act as physical barriers, or spatial partitions, separating between residential areas of ethnic groups.

In order to explore the potential function of land-uses as spatial partitions dividing Arab and Jewish residential areas, we analyzed the land-use characteristics of the dividing areas in each city, that constitute the division between statistical areas characterized by Arab and Jewish populations. This analysis revealed five types of large-scale spatial partitions dividing between Arab and Jewish neighborhoods: (a) major paths (e.g. main roads, streets and railroads); (b) open spaces (e.g. public open spaces, groves and orchards); (c) public land-use complexes (e.g. sports, culture and education institutes); (d) industrial areas; and (e) artificial barriers (e.g. walls and fences). While some of these spatial partitions (e.g. railroads, several open spaces and walls) are fully impenetrable, that is - do not allow access between their two sides, other partitions (e.g. main streets) do not act as a full barrier, but rather they make difficult the access between the two sides and they increase the visual and physical distance between the residents living in their two sides.

To illustrate these types of spatial partitions, for each city we identified the five adjacent statistical areas that exhibit the greatest differences in Arab population percentage, and analyzed the land-uses that are located in the dividing area between each adjacent statistical areas and that serve as spatial partitions. Table 6 presents the land-use characteristics of these dividing areas and Fig. 6 demonstrates selected cases of these spatial partition types.

In all cities, with the exception of Haifa, main roads, streets, and railroads were found to serve as barriers between Arab and Jewish areas. These long shaped features differ in size and functionality and vary from main urban streets (like Yefet streets in Jaffa), to major thoroughfares (like road No. 40 in Ramle - Fig. 6a) and railroads (like in Lod - Fig. 6b). In addition, large open spaces were also found to serve as partitions between Arab and Jewish areas. These open spaces vary from agriculture fields (in Acre, Ramle and Lod) and groves and orchards (in Lod and Ramle) to a large natural forest and mountain landscape in Haifa that create a natural barrier between Kababir neighborhood (with 72.3\% Arabs) and the surrounding Jewish neighborhoods (with $0.1 \%$ to $1 \%$ Arabs) (Fig. 6c). In Ramle, agriculture fields create conditions for a difference of nearly $78 \%$ in the Arab population percentage on either side. In addition, in all cities complexes of public land-uses (i.e. educational institutes, sports and culture, and other public services including cemeteries) tend to act as spatial partitions (see for example Fig. 6d. with the case of Jaffa). In other cases, artificial physical barriers appear to emphasize the boundaries between Arab and Jewish neighborhoods, for example, the old city wall in Acre which combine with various public land-uses to divide the Arab old city (with $98.9 \%$ Arabs) and the newer city (with $60.4 \%$ Arabs), and two concrete fences in Ramle that divide between Jewish and Arab neighborhoods (see Fig. 6e). 


\section{Land-use characteristics of the division areas between} Arab and Jewish residential areas

\begin{tabular}{|c|c|c|}
\hline & Land-use of spatial partition & $\begin{array}{l}\text { Difference in Arab population } \\
\text { percentage(with percentage of } \\
\text { Arab population in the two } \\
\text { adjacent statistical areas) }\end{array}$ \\
\hline \multirow[t]{5}{*}{ Acre } & Railroad, 4-digit thoroughfare & $54 \%(59 \% / 5 \%)$ \\
\hline & Railroad, cemetery, agriculture fields, open & $49.9 \%(59 \% / 9.1 \%)$ \\
\hline & Railroad, open space & $45.3 \%(50.3 \% / 5 \%)$ \\
\hline & $\begin{array}{l}\text { Acre`s old city wall, public open space, } \\
\text { education institutes, public services, sports } \\
\text { and culture land-uses }\end{array}$ & $38.5 \%(98.9 \% / 60.4 \%)$ \\
\hline & Railroad, 4-digit road, open space & $36.3 \%(41.3 \% / 5 \%)$ \\
\hline \multirow[t]{5}{*}{ Lod } & Agriculture fields, groves and orchards, & $98.5 \%(98.8 \% / 0.3 \%)$ \\
\hline & Open space & $98.1 \%(98.8 \% / 0.7 \%)$ \\
\hline & Open space, cemetery, groves and orchards & $97.6 \%(97.9 \% / 0.3 \%)$ \\
\hline & Regular urban street & $95.2 \%(98.8 \% / 3.6 \%)$ \\
\hline & Railroad, industry, open space & $94.3 \%(98.8 \% / 4.5 \%)$ \\
\hline \multirow[t]{5}{*}{ Ramle } & Agriculture fields, groves and orchards, & $77.7 \%(78.4 \% / 0.7 \%)$ \\
\hline & Open space, concrete fence & $74.2 \%(78.4 \% / 4.2 \%)$ \\
\hline & Groves & $65.4 \%(78.4 \% / 13 \%)$ \\
\hline & 2-digit areal road, open space, agriculture & $63.7 \%(68.5 \% / 4.8 \%)$ \\
\hline & $\begin{array}{l}\text { City stadium, tennis courts, city swimming } \\
\text { pool, cemetery, education institutes }\end{array}$ & $60.8 \%(63.9 \% / 3.1 \%)$ \\
\hline \multirow[t]{5}{*}{ Jaffa } & Cemetery, public services, education & $64.2 \%(79.5 \% / 15.3 \%)$ \\
\hline & Main street (Yefetst.) & $61 \%(70.3 \% / 9.3 \%)$ \\
\hline & Sports and culture, education institutes, & $54.2 \%(63.5 \% / 9.3 \%)$ \\
\hline & Main street (Yefetst.) & $52.6 \%(70.3 \% / 17.7 \%)$ \\
\hline & $\begin{array}{l}\text { Main street (Yefetst.), public services, } \\
\text { educational institutes, commercial area }\end{array}$ & $41 \%(79.5 \% / 38.5 \%)$ \\
\hline \multirow[t]{5}{*}{ Haifa } & Forest and groves, valley & $72.2 \%(72.3 \% / 0.1 \%)$ \\
\hline & Forest and groves & $71.8 \%(72.3 \% / 0.5 \%)$ \\
\hline & Forest and groves & $71.5 \%(72.3 \% / 0.8 \%)$ \\
\hline & Forest and groves, valley & $71.3 \%(72.3 \% / 1 \%)$ \\
\hline & Forest and groves, open space, industry & $71.1 \%(72.3 \% / 1.2 \%)$ \\
\hline
\end{tabular}


The Association between Land-Use Distribution and Residential Patterns: the Case of Mixed Arab-Jewish Cities in Israel
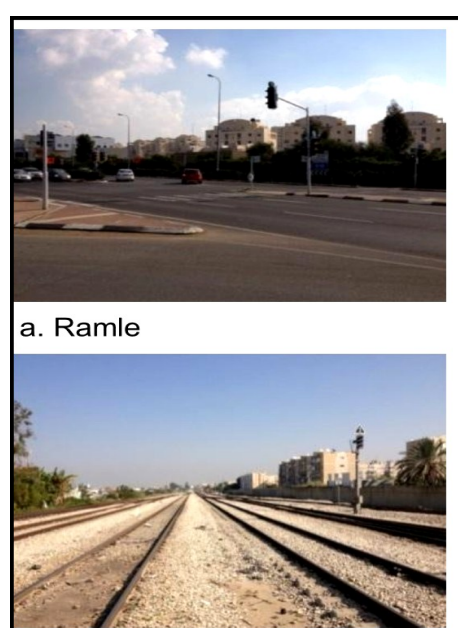

b. Lod

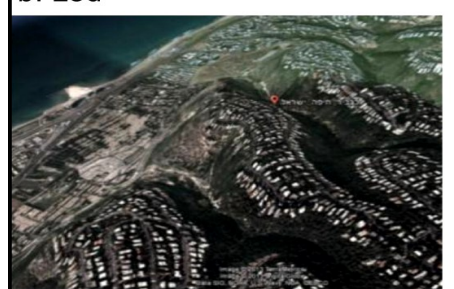

c. Haifa

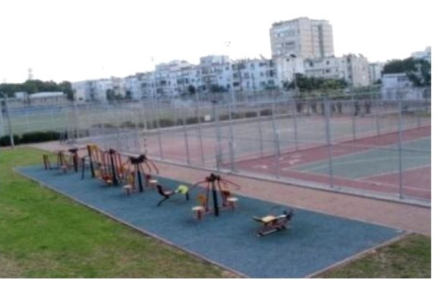

d. Jaffa

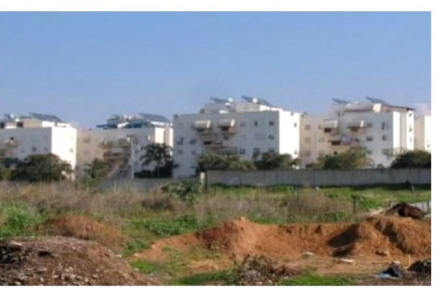

e. Ramle
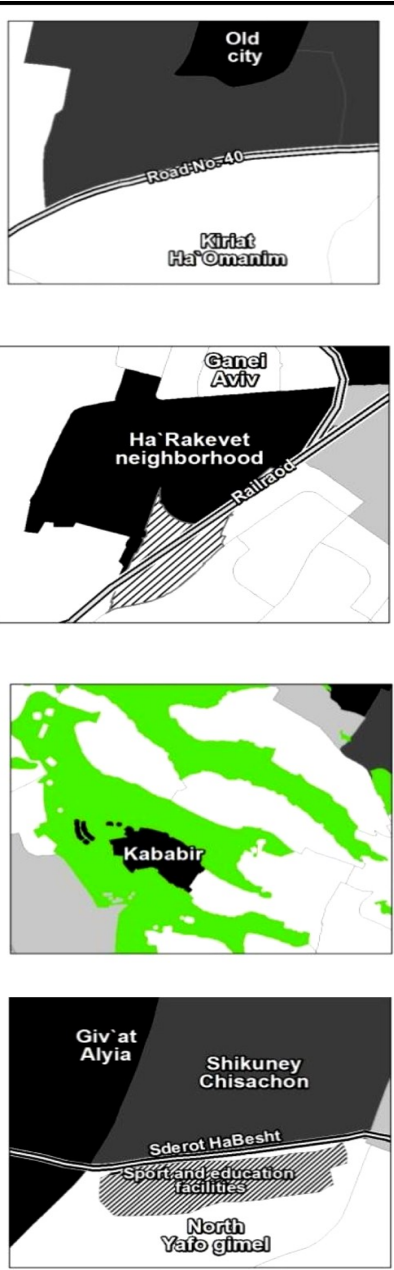

3. Public landuse complexes

4. Artificial

barriers

2. Open spaces

1. Major paths

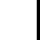

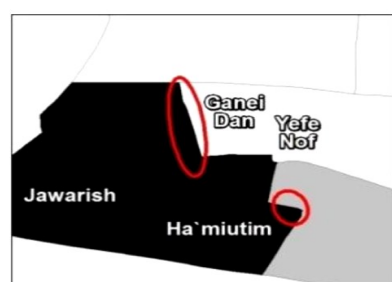




\section{Discussion and Conclusions}

In this paper we examined the Arab-Jewish residential patterns in five Israeli mixed cities in order to evaluate the influence of land-use distribution and spatial partitioning on dynamics of Arab-Jewish residential distribution patterns and the exposure between these population groups in urban areas. The use of GIS enabled us to quantitatively and visually integrate spatial, physical and social databases and analyze the association between these dimensions in the context of Arab-Jewish residential segregation.

Various factors have previously been found to potentially affect residential decisions, and in turn, residential segregation. Though ethnic preferences and attitudes to neighborhood diversity play a role in residential decisions, the built environment per se can also contribute to urban segregation due its own characteristics and spatial configuration (Omer 2011). For example, the physical distinctiveness of residential buildings, public spaces and other non-residential land-uses contributes to the formation and preservation of segregation between neighborhoods and residential areas populated by different social and ethnic groups (Brower 1996, Campbell et al. 2009). But at the same time, the functional and symbolic meanings ascribed to different places in the city also affect the everyday life routines of the residents and their residential choices. The results of this study have shown a positive significant correlation between the Arab population's residential pattern and the distribution of several types of land-uses, both functional and symbolic: mainly Muslim and Christian worship institutes, mixed residential buildings, and commercial land-uses. Against that, Arab-Jewish mixed residential areas are characterized by a relatively high percentage of various types of public land-uses (e.g. public services and commercial land-uses) - which potentially provide opportunities for encounters between Arabs and Jews and, as previously found, potentially affect inter-group contacts, and in turn, even decrease prejudice and social distance (Young 1990, Semyonov and Glikman 2009). Moreover, this finding also means that while the Arab population in the mixed cities suffers from lack of accessibility to various public spaces and services (e.g. cultural services) (Khamaisi 2008), the residence of Arabs in the mixed neighborhoods provides Arabs in these neighborhoods an "advantage" gained from the economic and political power of the majority group (i.e. the Jewish population), including access to public, educational and leisure services.

In addition, the results correspond with previous studies indicating that 'neutral' elements in the built environment (such as the presence of public institutions) tend to appear in cities' mixed areas (Omer 2011). Interestingly, this study has shown that areas that experienced a gentrification process and a decrease of the Arab population are characterized by a high percentage of symbolic land-uses (e.g. worship institutes), implementing that, similarly to the findings of Ben-Artzi (1980), the existence of worship land-uses are less important in Arab residential decisions.

Different land-use configurations also have an effect on the Arab-Jewish composition change in different areas of the cities. Results show that high rates of Arab-Jewish composition change characterize areas associated with commercial land-uses. However, a gentrification process, i.e. the increase of the Jewish population rate in these cities, had generally occurred in areas with more positive and attractive land-uses e.g., sports and culture, and public services.

The research had also revealed a correspondence between the Arab population distribution and the spatial continuity of the urban area, as defined by the distribution of land-uses. While various land-uses potentially affect the evolvement of ethnic residential patterns in mixed areas 
due to their functional and symbolic meaning, some of the land-uses serve as spatial partitions due to their physical and spatial characteristics that provide conditions that facilitate separation or segregation between the Arab and the Jewish populations. These partitions were shown to include main roads, streets, and railroads, as well as large open spaces and complexes of public service land-uses. The important consequences of these partitions are their effect on the physical and visual access between neighboring residential areas, and the resulting discontinuity of urban street systems. This finding also means that similarly to the argument of Grannis $(1998,2005)$, the segregated networks of residential streets may be more important for understanding urban racial composition/segregation than the Euclidean geographic indices traditionally used in the segregation research. Such physical elements create patterns of segregated street networks that lessen the visual access between neighborhoods and enhance the differentiation between Arab and Jewish neighborhoods - both, physically and symbolically.

The findings of this study support the notion that dynamics of ethnic residential distribution are bound up with the spatial distribution of non-residential land-uses that have different functional and symbolic meaning and with the physical dimensions of the land-uses. These functional, symbolic and physical attributes create conditions for the expansion of the Arab minority' residential pattern and have the potential to moderate, or in other cases to increase, exposure between Arabs and Jews.

A deeper understanding of the association between the urban built environment and the residential distribution can provide important input to urban spatial policymaking. Firstly, awareness of public land-uses that correspond with Arab residential change can assist the urban planners' response to the needs of the Arab population moving to other areas, and to plan the spatial distribution of public land-uses in a more equitable and appropriate way. Secondly, understanding the significance of the built environment's spatial continuity has major implications in policymaking aiming to moderate spatial segregation, for example, through improving spatial (visual and physical) access between residential Arab and Jewish areas.

In closing, it should be noted that in this paper we only illustrated the relation between the distribution of land-use and spatial partitions and the distribution of the Arab population, with no concern to the actual attitudes, feelings or perceptions of the Arab and Jewish populations. In addition, correlations, by nature, do not always imply causality; therefore, further research is still needed to examine the relationship between the built and the social environment, with respect to differential perceptions of various types of land-uses among the two populations, as well as to structural aspects such as urban economic processes.

\section{References}

AMIN A., THRIFT N. (2002), Cities: Reimagining the Urban, Polity Press, Cambridge. BEN ARTZI Y. (1980), Formation of a residential pattern and change of residence among the Arabs of Haifa, University of Haifa, Haifa, (in Hebrew). York. BERRY B. J. L., KASARDA J. D. (1977), Contemporary urban ecology, Macmillan, New

BOAL F. W. (2002), Belfast: walls within, Political Geography 21 (5), 687-694.

BOLT G., HOOIMEIJER P., VAN KEMPEN R. (2002), Ethnic segregation in the Netherlands: new patterns, new policies? Tijdschrift voor Economische en Sociale Geografie 93 (2), 214-220.

BOLT G., VAN KEMPEN R. (2010), Ethnic Segregation and Residential Mobility: Relocations of Minority Ethnic Groups in the Netherlands, Journal of Ethnic and Migration 
Studies 36 (2), 333-354.

BURGESS E. W. (1925), The Growth of the City, in: Park R.E., Burgess E. W., McKenzie R., Wirth L. (eds.), The City, University of Chicago Press, Chicago, 47-62.

BROWER S. (1996), Good Neighborhood, Wesport, CT, Preager.

CAMPBELL E., HENLY J. R., ELLIOTT D. S., IRWIN K. (2009), Subjective constructions of neighbourhood boundaries: lessons from a qualitative study of four neighbourhoods, Journal of Urban Affairs 31 (4), 461-490.

CLARK W. A. V. (1996), Residential patterns: Avoidance, Assimilation and Succession, in: Waldinger R., Bozorgmehr R. W. (eds.), Ethnic Los Angeles, Russell Sage, New York, 109138.

CLARK W. A. V. (2002), Ethnic preferences and ethnic perceptions in multi-ethnic settings, Urban Geography 23 (3), 237-256.

COLLINS C., WILLIAMS D. R. (1999), Segregation and Mortality: The Deadly Effects of Racism, Sociological Forum 14 (3), 495-523.

DUPONT V. (2004), Socio-spatial differentiation and residential segregation in Delhi: a question of scale?, Geoforum 35 (2), 157-175.

FALAH G. (1996), Living together apart: residential segregation in mixed Arab-Jewish cities in Israel, Urban Studies 33 (6), 823-857.

FALAH G., HOY M., SARKER R. (2000), Co-existence in Selected Mixed Arab-Jewish Cities in Israel: By Choice or by Default?, Urban Studies 37 (4), 775-796.

FIREY W. (1945), Sentiment and Symbolism as Ecological Variables, American Sociological Review 10 (2), 140-148.

GALSTER G., CUTSINGER J. (2007), Racial Settlement and Metropolitan Land-Use Patterns: Does Sprawl Abet Black-White Segregation?, Urban Geography 28 (6), 516-553. GIDDENS A. (1984), The Constitution of Society: Outline of the Theory of Structuration, Polity Press, Cambridge.

GILLILAND J. A., OLSON S. H., GAUVREAU D. (2011), Did Segregation Increase as the City Expanded? The Case of Montreal, 1881-1901, Social Science History 35 (4), 465-503. GOLLEDGE R. G., STIMSON R. J. (1997), Spatial Behavior: A Geographic Perspective, Guilford Press, New York. GRANNIS R. (1998), The Importance of Trivial Streets: Residential Streets and Residential Segregation, American Journal of Sociology 103 (6), 1530-1564.

GRANNIS R. (2005), T-Communities: Pedestrian Street Networks and Residential Segregation in Chicago, Los Angeles, and New York, City and Community 4 (3), 295-321. HADAS O., GONEN A. (1994), Jews and Arabs in a Mixed Neighborhood in Jaffa, Floersheimer Institute for Policy Studies, Jerusalem, (in Hebrew). HAMADAN H. (2006), Natzratllit as a Mixed City: Migration of Palestinians and Aspects of Spatial and Social Behavior, in: Fenster T., Yacobi H. (eds.), Israeli City or City in Israel? Questions of Identity, Meanings and Power, Van Leer Institute, Jerusalem, 110-134, (in Hebrew).

HIEBERT D., LEY D. (2003), Assimilation, cultural pluralism and social exclusion among ethnocultural groups in Vancouver, Urban Geography 24 (1), 16-44.

JOHNSTON R., POULSEN M., FORREST J. (2007), The Geography of Ethnic Residential Segregation: A Comparative Study of Five Countries, Annals of the Association of American Geographers 97 (4), 713-738.

KIPNIS B. A., SCHNELL I. (1978), Changes in the distribution of Arabs in mixed Jewish-Arab cities in Israel, Economic Geography 54, 167-180.

KHAMAISI R. (2008), The Arabic Population in the Mixed cities in Israel: Problems, Barriers and Challenges Toward Alternative Urban Policies, Shatil, Jerusalem, (in Hebrew). LEFEBVRE H. (1991), The Production of Space, Blackwell Publishers, Oxford. 
LESGER C. L., VAN LEEUWEN H. D. (2012), Residential Segregation from the Sixteenth to the Nineteenth Century: Evidence from the Netherlands, Journal of Interdisciplinary History 42 (3), 333-369.

LLOYD C. D., GREGORY I. N., SHUTTLEWORTH I. G., LILLEY K. D. (2012), Exploring change in urban areas using GIS: data sources, linkages and problems, Annals of GIS 18 (1), 71-80.

MASSEY D. S., DENTON N. A. (1988), The dimensions of residential segregation, Social Forces 67 (2), 281-315.

MONTELLO D. R. (2007), The contribution of space syntax to a comprehensive theory of environmental psychology, Paper presented at the $6^{\text {th }}$ International Space Syntax Symposium, Istanbul.

MONTERESCU D. (2011), Identity without Community, Community in Search of Identity: Spatial Politics in Jaffa, Megamot 47 (3-4), 484-517, (in Hebrew).

MORRILL R. L. (1970), The Shape of Diffusion in Space and Time, Economic Geography 46, 259-268.

OMER I. (2005), How ethnicity influences residential distribution: an agent-based simulation, Environment and Planning B 32 (5), 657-672.

OMER I. (2010), Residential Differentiation at Two Geographic Scales-The Metropolitan Area and the City: The Case of Tel Aviv, Journal of Urban and Regional Analysis 2 (2), 63-79.

OMER I. (2011), Spatial Configuration of Land-Uses and Arab-Jewish Residential Segregation in Jaffa, Built Environment 37 (2), 199-212.

OMER I., GOLDBLATT R. (2012), Urban spatial configuration and socio-economic residential differentiation: The case of Tel Aviv, Computers, Environment and Urban Systems 36 (2), 177-185.

OWUSU T. Y. (1999), Residential Patterns and Housing Choices of Ghanaian Immigrants in Toronto, Canada, Housing Studies 14 (1), 77-97.

PEACH C. (2000), The consequences of segregation, in: Boal F. W. (ed.), Ethnicity and Housing: Accommodating Differences, Ashgate Publishing, Aldershot, 10-23.

PFAUTZ H. W. (1967), On the City: Physical Pattern and Social Structure: Selected Writings of Charles Booth, University of Chicago Press, Chicago.

POLEDNAK A. P. (1993), Poverty, Residential Segregation, and Black/White Mortality Ratios in Urban Areas, Journal of Health Care for the Poor and Underserved 4 (4), 363-373. RABIN Y. (1987), The Roots of Segregation in the Eighties: the Role of Local Government Actions, in: Tobin, G. A. (ed.), Divided Neighborhoods: Changing Patterns of Racial Segregation. Newbury Park, CA: Sage Publications, 208-226, SCAFF A. H. (1948), Cultural Factors in Ecological Change on Mindanao in the Philippines, Social Forces 27 (2), 119-123.

SEMYONOV M., GLIKMAN A. (2009), Ethnic Residential Segregation, Social Contacts, and Anti-Minority Attitudes in European Societies, European Sociological Review 25, (6), 693-708.

SIBLEY D. (1995), Geographies of exclusion: Society and difference in the West, Routledge, London. SMITH S. J. (1987), Residential segregation: a geography of English racism?, in: Jackson P. (ed.), Race and Racism: Essays in Social Geography, Unwin Hyman, London, 22-42. SMOOCHA S. (2010), Index of Arab-Jewish Relations in Israel 2003-2009, University of Haifa, The Jewish Arab Center, Haifa, (in Hebrew). TAMARI Y. (2004), A Planning Survey in Arab and Mixed Neighborhoods of Ramle, The Arab Center for Alternative Planning and Bimkom, Jerusalem, (in Hebrew). VAUGHAN L. (2007), The spatial syntax of urban segregation, Progress in Planning 67 (3), 205-294 WEISMAN J. (1981), Evaluating Architectural Legibility: Way-finding in the Built 
Environment, Environment and Behavior 13 (2), 189-204.

WONG D. W. S. (2003), Implementing spatial segregation measures in GIS, Computers, Environment and Urban Systems 27 (1), 53-70.

WU X. B., SUI D. Z. (2001), An initial exploration of a lacunarity-based segregation measure, Environment and Planning B: Planning and Design 28 (3), 433-446.

YACOBI H. (2002), The architecture of ethnic logic: Exploring the meaning of the built environment in the 'mixed' city of Lod, Israel, Geografiska Annaler: Series B, Human Geography 84 (3-4), 171-187.

YACOBI H. (2008), Architecture, Orientalism, and Identity: The Politics of the Israeli-Built Environment, Israel Studies 13 (1), 94-118.

YIFTACHEL O., YACOBI H. (2003), Urban ethnocracy: ethnicization and the production of space in an Israeli 'mixed city', Environment and Planning D: Society and Space $21(6), 673-693$. Princeton.

YOUNG I. M. (1990), Justice and the Politics of Difference, Princeton University Press,

Initial submission: 10.02.2014

Revised submission: 17.03.2014

Final acceptance: 10.06 .2014

Correspondence: Department of Geography and Human Environment, Tel Aviv University, Tel Aviv-Yafo, 6997801, Israel

E-mail: ran@eslab.tau.ac.il 